Tunçer, P. / Sosyal Bilimler Araştırmaları Dergisi. I, (2012): 131-156

\title{
Değişim Yönetimi Sürecinde İnsan Kaynakları ve Performans Yönetimi
}

\section{Polat Tunçer ${ }^{1}$}

\begin{abstract}
Özet
Değişim çağımızın en önemli özelliğidir; değişimi yönetmek ise günümüz örgütlerinin en temel sorunlarından birisidir. Değişime ayak uyduramayan örgütlerin etkinliği ve verimliliği düşmekte ve kendilerinden beklenen taleplere cevap veremez hale gelmektedirler. Bu nedenle değişimin başarılı bir biçimde yönetilmesi, örgüt bakımından hayati öneme sahiptir. $\mathrm{Bu}$ makalenin amacı, hayatta kalabilmek için değişime uyum sağlamak zorunda olan örgütlerin, insan kaynakları ve performans yönetimi yaklaşımlarını kullanarak değişime uyum sorunlarını daha kolay çözebileceklerini göstermektir. Konuyla ilgili literatür taraması yapılmış ve elde edilen bilgiler analiz edilip değerlendirilmiştir. Bu bağlamda değişim sürecine uyum sağlamak, kendisini yenilemek ve başarılı olmak isteyen örgütler, çeşitli yönetim tekniklerinden yararlanmak zorundadırlar. Bu yöntemler örgütün içinde bulunduğu şartlara ve sahip olduğu imkânlara göre değişebilmektedir. İnsan kaynağının önemi nedeniyle pek çok örgüt değişimi yönetmek, etkinliğini ve verimliliğini artırmak için insan kaynakları ve performans yönetimi tekniklerinden yararlanmaktadır. İnsan kaynağının seçilmesi, istihdamı ve eğitilmesi gibi pek çok husus, değişim sürecinde insan kaynağından beklenen yararın elde edilmesinde etkilidir. Ayrıca süreçte örgütün ve çalışanların amaç, hedef ve menfaatleri birlikte gözetilmeli ve performans artırıcı tedbirler ihmal edilmemelidir. Örgütsel etkinliği ve verimliliği artırmak için çalışanların performanslarını değerlendirme ve ödüllendirmenin yanında insan kaynakları yönetimi felsefesinin örgütsel düzeyde uygulanması gerekir. Örgütsel değişimi gerçekleştirmenin pek çok yöntemi bulunmakla birlikte, örgütün en önemli kaynağı olan insana yönelik yönetim tekniklerinin kullanılmasıyla, örgütsel değişim daha başarılı bir biçimde gerçekleştirilir.
\end{abstract}

Anahtar kelimeler: Değişim, Değişim Yönetimi, İnsan Kaynakları Yönetimi, Performans Yönetimi.

\section{Human Resources and Performance Management in the Change Management Process}

\footnotetext{
${ }^{1}$ Öğretim Görevlisi Dr. Ondokuz Mayıs Üniversitesi, Samsun Meslek Yüksekokulu Atakum Kampusu /Samsun e-mail: poltuncer@gmail.com Tel.: 05303280844
} 


\begin{abstract}
Change is the most important feature of our age and the managing the change is one of the most fundamental problems of today's organizations. The efficiency and productivity of the oganizations which couldn't keep up with the change have declined and they've become unable to handle the expected demands. Therefore, successful management of change has the vital importance for the organizations. The purpose of this article is to show the organizations which have to adopt the change to survive, to be solved the problems of adaptation to change more easily using the human resources and performance management approaches. The literature review was conducted and the data obtained was analyzed and evaluated. In this context, it's seen that the organizations have to benefit from various management techniques in order to be able to manage the change process succesfully. These methods may change depending on the conditions of the organizations and the facilities they have. Due to the importance of human resources, many organizations benefit from human resources and performance management techniques in order to increase the efficiency and productivity of them. In the process of change, many issues such as the selection, recruitment and training are effective in achieving the expected benefits of human resources. Moreover, the precautions to enhance the performance of the organization and the employees shouldn't be neglected in the process. In order to improve the organizational efficiency and productivity, the human resource management philosopy and the principles of performance management must be implemented at the organizational level. As a conclusion, although there are many methods to accomplish organizational change, the organizational change is carried out more successfully with the help of human resources and performance management.
\end{abstract}

Key words: Change, Change Management, Human Resources Management, Performance Management.

\title{
GíRiş
}

Değişimi yönetmek oldukça güçtür; çünkü bu sürece etki eden örgütsel faktörlerin sayısı oldukça fazladır. Örgüt hayatta kalabilmek için, sürekli değişen çevresine uyum sağlamak zorundadır. Böyle bir uyum için örgütün yap1, süreç ve yöntemlerini değiştirmesi yeterli olmayıp, ayrıca örgütün insan kaynağını da bu değişime hazırlaması gerekir. Bunun için; çalışanların bilgi ve görgüleri artırılmalı, onları motive edecek ve performanslarını yükseltecek yöntem ve uygulamaların seçimine ve uygulanmasına dikkat edilmelidir. 
Örgütte gerçekleştirilecek bir değişim, örgütte yerleşmiş olan pek çok alışkanlıkları ve iş yapma biçimlerini değiştirdiği gibi, çalışanların konumlarını ve durumlarını da değiştirir. $\mathrm{Bu}$ nedenle değişim, bundan olumsuz yönde etkilenenlerin direnciyle karşılaşır. Bütün değişimler az ya da çok dirençle karşılaşır. Önemli olan bu süreci kısa sürede ve başarılı bir biçimde gerçekleştirmektir. Çalışanların desteği alınmadan ve değişim sürecini benimsemeleri sağlanmadan değişimin başarılı bir biçimde yönetilmesi ve uygulanması mümkün değildir. Değişim sürecine insan kaynağının yeterli ölçüde katılabilmesi ve onların bilgi ve becerilerinden önemli ölçüde yararlanılabilmesi için performans yönetiminin de bu süreçte kullanılması gerekir. Değişim sürecine yaptıkları katkı ölçüsünde ödüllendirilen ya da değişime yaptığı katkı ve gösterdiği performans nedeniyle örgüt yöneticileri tarafindan takdir edilen çalışanlar, değişim sürecine destek olmaya devam ederler; aksi taktirde değişime karşı açık ya da gizli dirençte bulunabilecekleri gibi performanslarını düşürerek de bu süreci engellemeye çalışabilirler.

Çalışanlar tatmin edilmeden ve onların değişim yönündeki performansları ödüllendirilmeden örgütsel değişimi başarılı bir biçimde yönetmek mümkün değildir. Bu bağlamda örgütsel etkinlik ve verimliliğin sağlanması ya da artırılması için gerçekleştirilecek değişimin yönetilmesinde, insan kaynakları ve performans yönetiminden yararlanılabilir. İnsan kaynağını etkin ve verimli kullanamayan hiçbir örgüt değişimi başarılı bir biçimde yönetemez.

\section{A. Değişim Yönetimi}

Yönetim, örgütsel bir düzen içinde, başarmak, görevi yerine getirmek ve amaçlara doğrudan ulaşmak için kaynakların düzenli kullanıldığı ve toplandığ1 süreçtir (Hitt vd, 2009: 25). İyi yönetim, amaçlara ulaşma ve mümkün olduğu kadar etkili çalışmayla ilgilidir (Robbins ve DeCenzo, 2008: 6). Değişim yönetimi, yöneticilerin örgütte uygulamayı amaçladığı stratejilerin, politikaların ve süreçlerin çalışanlar tarafından doğru algılanması ve uygulanması amacıyla bunlar arasındaki etkileşimi dengeleme sanatıdır (Çetin, 2008: 129). Değişim yönetimi, çok hassas dengeler üzerine kuruludur. Değiş̧imi yönetenlerle stratejileri uygulayanlar arasındaki iletişimi yönetmek, değişimin gerçekleşebileceği bir örgüt ortamı yaratmak ve işyerinde başarılı bir dönüşüm için gerekli olan duygusal bağlantıları yönetmek değişim yönetiminin önemli alanlarıdır (Duck, 1999: 62). 
Hızlı ve kaçınılmaz olan değişim bir bütündür ve yaşamın tüm alanını kapsamaktadır. Etkili bir şekilde değişime cevap verebilmek için, değişimi etkileyen faktörlerin neler olduğunun bilinmesi ve değişime nasıl başlanacağına cevap verilmesi gerekir. Değişimin hızı sadece örgütte çatışma ve aksamalara neden olmaz aynı zamanda çalışanları oldukça büyük strese sokar (Cornell, 1996: 23). Örgütsel enerjinin boşa harcanmasına neden olan stres aynı zamanda örgütsel amaçlara ulaşmayı güçleştirir. Bu nedenle değişim yönetiminin başarısı için değişimin oluşturduğu stresin örgütsel ortamdan uzaklaştırılması gerekir.

Başarılı bir değişim için çalışanların düşünceleri ve inançları örgütsel değişimi destekleyecek biçimde değiştirilmelidir. Paslanmış düşünceler, paslanmış makinelerden daha da tehlikelidir. Bugünkü güçlü değişim ortamında hâlâ dünkü inançlara göre çalışmaya devam eden herhangi bir örgütün, değişen çevresiyle gerçek anlamda uyum içinde bulunabilmesi mümkün değildir (Toffler, 1989: 48). Çevresindeki değişimlere karşı açık olan ve öğrenerek uyum sağlama yeteneği gösteren; belirli bir kimliğe, kurum kültürüne, yaratıcılığa, firsatları değerlendirme gücüne, finansal kaynaklarını etkin bir biçimde kullanma becerisine sahip olan örgütler yaşama şansına sahiptir (Yazıc1, 2001: 39). Ancak değişimi yönetmek oldukça zordur. Çünkü mevcut sistemde yapılan herhangi bir değişikliğin, neredeyse sınırsız etkileri vardır (Schumacher, 2010). Bu nedenle değişimin planlanması gerekir; değişimin başarısı büyük ölçüde onun planlanmasına bağlıdır. Ancak kapsamlı bir değişim planı yanında böyle bir çalışmanın bilinçli ve kararlı bir şekilde sürdürülmesi gerekir (Pritchard, 2010).

Çevre şartlarının değişmesiyle birlikte, yeni firsatlar ve tehditler ortaya çıkar. Bu durum yeni güç ilişkilerinin ve çalışma yöntemlerinin tekrar gözden geçirilmesini gerektirir. Yeni bir sisteme uyum sağlama sürecinde ortaya çıkabilecek sorunlar değişim yönetimini zorunlu kılar (White, 2000: 162). Her örgütün kendine has sorunları ve özellikleri vardır; bu nedenle örgütsel değişim farklı yaklaşımlar ve müdahaleler gerektirir. Değişim ajanları tarafından en iyi strateji değil örgütsel gerçeklere en uygun değişim stratejisi tercih edilmelidir (Werkman, 2009: 664). Değişimi yönetmek için birkaç farklı yaklaşım vardır. Ancak hiçbiri diğerinden üstün değildir. Özel bir yaklaşımın uygunluğu içinde bulunulan koşullara bağlıdır (Burnes, 1997: 753). Durumsallık yaklaşımı bu süreçte de geçerlidir. Her örgütün kendine has koşulları ve çevresi bulunmaktadır. Dolayısıyla değişim sürecinde kullanılacak yöntem ya da yöntemler seçilirken örgütün içinde bulunduğu koşullar göz önünde 
bulundurulmalıdır. Değişimin başarılı bir biçimde yönetilmesi böyle bir yaklaşımın benimsenmesine bağlıdır.

Değişim yönetiminin ilk şartı değişim ihtiyacının hissedilebilmesidir. Değişimin yönetilmesinde dikkate alınacak bazı parametreler ve değişkenler vardır. Örgüt içi değişkenler; görev, yapı, teknoloji ve insan unsurudur. Örgütsel parametreler ise; müşteriler, rakipler, uluslararası politikalar, yasal düzenlemeler gibi birçok çevresel etmenlerden oluşur (Genç, 2005: 303-304). Değişim ihtiyacının hissedilmesi örgütte değişim için itici bir kuvvet oluşturacaktır. Yalnız bu duygunun çalışanların büyük bir çoğunluğu tarafından paylaşılması gerekir. Tepe yönetimi tarafından arzu edilen değişimin çalışanlar arasında destek bulması için örgütte bir araştırma ve değerlendirme yapmak yerinde olacaktır. Çalı̧̧anlarda değişim yönünde bir talep ya da duygu bulunmuyorsa, tepe yönetimi değişimi gerçekleştirmeden önce çalışanlarını bu değişim olgusuna duygusal yönden hazırlamalıdır.

Etkili değişim yönetimi, mevcut çalışma koşullarının gelecekte örgüt vizyonuna ulaşmak için gerekli olan şartları yaratır (Yeniçeri, 2002: 147). Değişimi sürekli olarak küçük parçalara ayırıp yönetmek Taylor'un bilimsel yönetiminde kalan bir mirastır. Hâlbuki değişimdeki görev, parçaları değil, dinamiği yönetmektir. Zorluk, fiziksel işleri kopyalamakta değil, zihinsel işlerde yenilik yapmaktır. Hedef insanlara stratejik düşünmeyi, kalıpları tanımayı, sorunları ve firsatları daha ortaya çıkmadan önce tahmin etmeyi öğretmektir (Duck, 1999: 63).

Örgütlerin yıllardır yüz yüze geldiği değişiklikler yalnızca ekonomik ve teknolojik değil, aynı zamanda demografik, politik, toplumsal, felsefî ve dünya görüşünde meydana gelen değişikliklerdir. Önceden tahmin edilmesi oldukça güç olan değişimi yönetmede başarılı olabilecek tek politika, geleceğin oluşturulmasına çalışmaktır. Geleceği yönetmeye çalışmak oldukça risklidir, ancak bunu hiç denememek çok daha risklidir (Drucker, 2000: 107). Değişim ihtiyacı apaçık ortaya çıktığında değişimi başarılı bir şekilde gerçekleştirebilmek için mevcut yönetsel engeller kaldırılmalı, değişimi gerçekleştirmeden önce; şu sorulara cevap aranmalıdır (Hitt vd, 2009: 451):

- Ne kadar değişim yeterlidir?

- Değişim ne kadar hızlı yapılmalıdır?

- İstikrarlı ve sürekli, minimum bir ihtiyaç düzeyine karşı dengelenmiş olan, sürekli değişim ihtiyacı ne olmalıdır? 
- Değişim sürecinin büyük oyuncuları kimler olmalı ve onların rolleri ne olmalıdır?

- Belirli değişiklikler yoluyla muhtemelen kim tamamen zararlı ve faydalı olabilir?

Değişim yönetimi, hareketli parçalardan oluşan karmaşık bir yapının hassas dengelerini sağlamakla ilgilidir. Değişim çabasında önemli olan şey, her parçayı yalıtılmış olarak ele almak değil, bütün parçaları birbirine bağlamak ve dengelemektir. Değişim yönetiminde; örgütsel fonksiyonların birbirini nasıl dengelediğini, bir unsuru değiştirmenin diğerlerini nasıl değiştirdiğini, değişim hız ve sıralamasının ya da önceliklerinin bütün yapıyı nasıl etkilediğini anlamak, oldukça hassas bir görevdir (Duck, 1999: 63). Değişim çalışmalarında şu temel prensipler göz önünde bulundurulmalıdır: Çalışmalar performansı ve etkinliği artıracak biçimde yönlendirmeli; değişim, stratejik kararlar ve yapısal düzenlemelerle desteklenmelidir. Değişim çabaları, ekip çalışması ile sürdürülmeli, fikir ve işbirliği sağlanmalı; sürekli öğrenme ve iyileştirme yaklaşımı birlikte kullanılmalıdır. Örgütün enerjisini pek çok soruna dağıtmak yerine, sonuç alıncaya kadar birkaçı üzerinde odaklanmak daha yararlıdır (Düren, 2000: 232).

Değişim sürecinin yol açtığı ekonomik, sosyal, kültürel ve yapısal sorunlar, bilgi çağının temel sorunları arasında yer alır. Değişimin yaşanmadığı hiçbir alan kalmadığı gibi, yönetimle ilgili kavram ve zihniyetler de değişmiştir. Pek çok alanda çarpıcı değişimler yaşanmaktadır; gelecek geçmişin basit bir uzantıs1 ya da kopyası olmayacaktır. Son veriler geleceğin yöneticisinin büyük değişim ve zorluklarla başa çıkmak zorunda olacağını göstermektedir. $\mathrm{Bu}$ zorluklar aş11ırken, yöneticinin göz önünde bulundurması gereken dokuz alan bulunmaktadır: Teknoloji, çevre, bilgi yönetimi, iş dünyası, örgütsel bağl1lık, örgüt yapıları, örgütün amaçlarının yeniden tanımlanması, girişimcilik, iletişim, ve çokulusluluk (Hodgetts, 1997: 7).

Bir örgüt değişmeden ne kadar uzun süre devam ederse, değişim fikirlerinin ortaya konması o kadar zorlaşır. Değişim gerçekleşip de sonuç olumsuz olduğunda, insanlar gelecekteki değişim konusunda isteksiz davranabilecekleri gibi geçmişteki başarılı değişimler de insanları değişime açık hale getirebilir (Maxwell, 1998: 89). Bu nedenle örgütün başarılı uygulamalara imza atması oldukça önemli bir husustur. Çünkü örgütsel başarı yeni başarıları desteklerken, başarısızlıklar da çalışanlarda umutsuzluklar yaratarak örgütsel performansı düşürür. Sonuçta başarısız bir değişim uygulaması örgütün sonunu 
hazırlayabilir.

Örgütsel değişime sistem perspektifinden bakıldığında, organik modelde, değişim öncelikle bir uyum sorunudur. Sistem hareketli bir bütün olarak ya da belirli fonksiyonları ve alt sistemleri aracıllı̆ıyla değişen çevreye uyum sağlamaya ve dengesini korumaya çalışır. Örgüt, değişime gösterdiği tepkiyle, negatif geribildirimi değerlendirir ve kendisinden beklenen davranış ile örgütsel davranış arasındaki farklılıkları tespit etmeye çalışır. Bu bağlamda değişim sürecinde çevre, geribildirim ve adaptasyon süreci devam eder. Sibernetik model ise, bütün sisteme dağıtılmış ve tekrarlanan hiyerarşik şekilde organize edilmiş iletişim mekanizmaları ile sürecin daha ayrıntılı kontrolünü sağlar. Sistemdeki bilgi akışı ve akışın ortaya çıkardığı sonuçlar örgütsel değişim için önemlidir. Ayrıca sistem yaklaşımı, Proaktif değişim ihtimaline açık olan çevre taramasını da kapsar. Organik modelde değişim, dış tehditlere cevap olmak üzere gereklidir. Kaosun kenarında ve dengeden uzak bir sistem, dönüştürücü değişim sürecine girmiş demektir (Beeson ve Davis, 2000: 179181).

Örgüt sistematiği içinde yapılacak her değişikliğin, sistemin diğer alt sistemleriyle etkileşimini, satranç hamlesi yaklaşımıyla değerlendirmek ve muhtemel sonuçlarını göz önüne almak gerekir. Aksi takdirde, sistemin bir noktasında sistemden bağımsız ortaya konan bir iyileştirme ya da değişiklik, sistemin diğer noktalarında sistemin bütününe zarar verecek tarzda olumsuz sonuçları doğurabilir. Değişimin başarılı bir şekilde yönetilmesi için; değişim bütünlük içinde ele alınmalı, değişim için uygun bir örgüt kültürü ve ikilimi yaratılmalı, sürekli bir çevresel duyarlılı̆ga sahip, esnek bir örgütsel yapı oluşturulmalı, dönüştürücü liderlikle birlikte koordinasyon sağlanmalıdır.

Değişim gerçekleştiği zaman, örgüt yeni bir denge arar; bu durumda bireylerin yeni uyumlar göstermeleri gerekir. Çalışanlar gerçekleşen değişimlere yeterli uyumu göstermezlerse örgütte bir dengesizlik oluşur. Bu bağlamda yönetimin amac1, değişimin bozduğu grup dengesini ve kişisel uyumu düzeltmek ve korumaktır (Davis, 1988: 209). Çalışanlar örgütün bir üyesi oldukları gibi aynı zamanda örgüt içinde bir grubun da üyesidir. Örgütsel değişim kişiyi bireysel olarak etkilediği gibi onun üyesi bulunduğu grubu da etkiler. Bunlar birbirinden bağımsız düşünülemez. Çünkü insanların davranışı, tutum, inanç ve değerleri ait oldukları gruplarca belirlenir. Değişim büyük oranda grupların yapısından etkilenir ve değişim girişimleri grup dinamikleri ile 
ilişkilidir. Aynı zamanda değişim de bireyleri, grupları ve örgütsel dinamikleri aynı derecede etkiler (White, 1998: 103).

Değişim kolay değildir ve gelişmenin düzeyi değişim konusundaki kararlılığa bağlıdır. Değişim düşüncesi insanlarda belirsizlik hissine yol açar. $\mathrm{Bu}$ nedenle meydana gelen değişim olumlu da olsa, yine de belirsizlik yaratacağ için, bir an önce çalışanlar bu yeni durumla ilgili bilgilendirilmeli ve şüpheler dağıtılmalıdır (White, 1998: 117). Bir örgütün değişimi uygulamaya koyabilmesi ve var olan entelektüel sermayesini tam olarak kullanabilmesi için öncelikle, itimat ve güven ortamının oluşturulması gerekir (Buzan vd, 2001: 156). Güvensiz bir örgüt ortamı strese ve çatışmalara yol açtığı gibi bozulan örgüt iklimi çalışanların verimliliğini düşürür. Enerjisinin büyük bir bölümünü faydasız kısır çekişmelere harcamak zorunda kalan çalışanların; örgütsel performansa katkıları azalır. Artık örgütteki uyum ve işbirliği kaybolmuş, örgütün insan kaynağı iş yerine dedikodu üretmektedir.

Çalışanların genellikle değişimle ilgili iki seçenekleri vardır. İlki, isteseler de, istemeseler de değişimden kaçamazlar. İkincisi de, ya değiş̧ime uyum sağlar, ya da onun kurbanı olurlar (Buzan vd, 2001: 6). Örgütsel açıdan da durum aynıdır; ya değişecek ya da yok olacaktır. Bu nedenle örgüt değişime uyum sağlamak için planlı, yöntemli ve kararlı bir biçimde değişimi uygulamalıdır. Değişim yönetiminin başarılı olması için üzerinde durulması gereken hususlar şöyle özetlenebilir (Düren, 2000: 236):

- Değişime duyulan ihtiyaç ciddi olarak teşhis edilmelidir.

- Değişimle ilgili örgütün tümü tarafından paylaşılacak bir vizyon ve uyumlu stratejiler yaratılmalıdır.

- Aktif katılımı sağlamak için çalışanlar arasında koalisyon oluşturulmalıdır.

- Değişimden en çok etkilenecek kişi ve mevkilere motor roller verilerek, onlar teşvik edilmelidir.

- Değişim sorumlularını ve proje liderlerini, sevilen ve karizmatik özellikleri olan kişilerden seçmelidir.

- İletişim, ikna ve eğitim faaliyetlerine gereken önem verilmelidir.

- Katılımci ve yaratıcı yöntemleri ön planda tutan çabalara ve faaliyetlere ağırlık verilmelidir.

- Değişim faaliyetleri örgütün maddi ve manevi unsurları arasındaki ilişkileri, dengeyi ve uyumu, en yumuşak şekilde yeniden revize edecek tarzda yönlendirilmelidir. 
- Yeni yöntem ve davranışların, örgüt içinde yaygınlaştırılması ve entegrasyonu sağlanmalıdır.

Değişim ve süreklilik; birbirine zit şeyler gibi görünse de aslında değillerdir; bunlar yalnızca kutuplardır. Bir örgüt değişim liderliği için hazırlandıkça, içte ve dışta sürekliliği sağlamaya yönelik çalışmalara daha çok ihtiyaç duyacak; hızlı değişim ve süreklilik arasındaki dengenin kurulması gerekliliği de artacaktır. Değişim ve sürekliliği dengede tutabilmek için, örgütün ihtiyaç duyduğu bilgilerin sağlanması ve kullanılması bu süreçte önemlidir. Kötü veya güvenilir olmayan bilgiler sürekliliği bozduğu gibi örgütsel ilişkileri de yozlaştırır (Drucker, 2000: 104-106).

Değişim bir yandan sorunlara çözüm getirirken diğer yandan yeni sorunların çıkmasına sebep olabilir Bu nedenle ortaya çıkabilecek sorunların önceden tahmin edilip gerekli tedbirlerin alınması gerekir. Değişim yeni alışkanlıklar edinmenin yanısıra eski alışkanlıklarından kurtulmayı da gerektirir; bu kurtulma yeni alışkanlıkları edinmekten daha güçtür. Bu nedenle onlara uyum için bir mühlet verilmeli ve anlayışlı davranılmalıdır. Çünkü her değişim bir süreçtir. Yıllardır tekrarlanan ve böylece de kolaylaşan örgütsel hareket tarzları ve iş yöntemlerinin değiştirilebilmesi için belirli bir zamana ihtiyaç vardır.

Değişime insan kaynağından başlamalıdır. Değişimin yeni imkânlar ve firsatlar getireceği çalışanlara anlatılmalı ve onların bu konuda desteği sağlanmalıdır. Değişim konusunda insan kaynağının zihinsel yapısı değiştirilmeden bu konuda başarılı olmak mümkün değildir. Onlarsız değişimin başarılamayacağı düşüncesi ve duygusu çalışanlarda uyandırılmalı, örgütün en değerli varlığı oldukları da hissettirilmelidir. Aksi taktirde değişim süreci başarısızlıkla sonuçlanır. Değişimi uygulayacak olan çalışanlar örgütün en değerli kaynağıdır ve onlara rağmen hiçbir iş başarılamaz. Bu nedenle çalışanlar arasında işbirliği ve takım ruhu oluşturulmalı, insan kaynakları ve performans yönetimi tekniklerinden yararlanılmalıdır.

\section{B. İnsan Kaynakları Yönetimi}

İnsan kaynağı bir örgütün amaçlarını gerçekleştirmede etkili olan temel faktörlerden birisidir. Örgütsel değişime ihtiyaç duyulduğunda bu değişim, çalışanların desteğiyle ve katkılarıyla gerçekleştirilebilir. Bu süreçte, değişimin amaç ve hedefleri doğrultusunda çalışanların harekete geçirilmesi, insan kaynakları yönetimi anlayışının da bu doğrultuda değiştirilmesi gerekir. Bir 
başka deyişle değişimin başarılabilmesi için insan kaynakları yönetimi yaklaşımının ve uygulamalarının örgütsel değişimi desteklemesi gerekir.

\section{1. İnsan Kaynakları Yönetimi Kavramı}

Hammadde, enerji, sermaye, işgücü ve girişim olarak sıralayabileceğimiz üretim faktörleri içinde başarıya ulaşmayı sağlayan en önemli unsur insan faktörüdür. Çünkü insan hem fiziksel hem de düşünsel gücüyle örgüte hizmet etmekte ve aynı zamanda da diğer üretim faktörlerini organize ederek üretimin gerçekleşmesini sağlamaktadır (Yüksel, 2007: 5). İnsan kaynakları yönetimi, örgütün amaç ve hedeflerine ulaşabilmek için; çalışanların seçimi, yerleştirilmesi, eğitimi, gelişimi, motivasyonu ve beklenen performansın sürekliliği için gerekli olan etkinliklerin yönetimidir (Dolgun, 2007: 2). İnsan kaynakları yönetimi aynı zamanda planlama, örgütleme, yönlendirme, koordinasyon ve denetleme ile de ilgili bir disiplindir.

\section{2. İnsan Kaynakları Yönetimi Değişim Yönetimi İlişsisi}

Çağımızdaki teknolojik yenilikler ve gelişmeler değişim sürecini hızlandırmış; bu nedenle de örgütlerin değişme uyum sağlamaları zorlaşmıştır. Ancak insan kaynağını iyi yöneten örgütler çevrelerinde meydana gelen değişime ayak uydurmakta zorluk çekmezler. Çünkü değişim ancak, çalışanlarla birlikte ve onların niteliklerine dayalı olarak gerçekleştirilirse başarılı olabilir. Örgütün en büyük zenginliği donanımlı ve değişime açık çalışanlara sahip olmaktır. Bilgiye, öğrenmeye ve değişime açık bir insan kaynağına sahip olmak değişim sürecini oldukça kolaylaştırır. Ancak değişim sürecinde insan kaynağının etkili ve verimli bir biçimde çalıştırılması bu başarı da önemli bir rol oynar. İnsana yapılan yatırımın örgütsel değişim ve dönüşümü gerçekleştirirken etkili olacağı unutmamalıdır. Değişimi üstlenen örgütün tepe yönetimi, insan kaynağını yerli yerinde kullanarak israf etmemeli, onların zaman ve enerjilerinin çok azının bile boşa gitmemesi için gerekli tedbirleri almalıdır. Çoğu zaman değişim sürecinin başarısızlığı, elindeki insan kaynağını etkili ve verimli kullanamayan, ondaki iş başarma potansiyelini açığa çıkaramayan yöneticilerden kaynaklanır.

Örgütler sürekli değişen bir ortamda başarılı olabilmek için insan kaynağının fiziksel ya da düşünsel potansiyelini kullanır. Üretim yapabilmek için gerekli olan insan dışı faktörler yine insanın varlığı ile anlam kazanır. Örgütler, verimli ve etkili çalışabilmek için donanımlı insanları işe almalı, onları bünyesinde tutmalı ve motive etmelidir. Ayrıca mal ve hizmetleri, uygun yöntemler kullanarak minimum maliyetle üretebilmeli ve verimliliğe 
odaklanmalıdır (Yüksel, 2007: 1-2). Örgütler değişim sürecinde gerekli olan değiştirme ve dönüştürme gücünü insan kaynağında bulur. Yeterli, yetenekli ve donanımlı insan kaynağı, değişimi yönetmede örgütün en temel potansiyel gücünü oluşturur. Örgütsel amaç ve hedefler bu güç sayesinde etkili ve verimli bir biçimde gerçekleştirilebilir.

İnsan kaynakları yönetiminin; insan kaynağının verimli kullanılması ve çalışanların ihtiyaçlarının karşılanması olmak üzere iki temel felsefesi vardır. İnsan bir kurumun sadece en değerli kaynağ 1 değil en önemli zenginliğidir. İnsan kaynağının yeri bir başka kaynakla asla doldurulamaz (Sabuncuoğlu, 2000: 2-4). Başarı için girdilerin hepsi önemli olmakla birlikte rekabet avantaj1 sağlayan en önemli kaynak, insan kaynağıdır (Benligiray, 2007: 3). İnsana sayg1, eşitlik, liyakat, kariyer, verimlilik, güvence, tarafsızlık, açıklık, bilimsellik, disiplin ve halef yetiştirme ilkesi gibi, insan kaynakları yönetimi alanındaki, temel değerler, çalışanları örgüte bağlamada ve onların tüm potansiyel güçlerini örgüt için harcamalarını sağlamada oldukça etkilidir.

İnsan kaynağının değişim sürecinde etkili ve verimli kullanılabilmesi için insan kaynakları planlamasının yapılması gerekir. Değişimin başarısı özenle yapılacak böyle bir planlamaya bağlıdır (Karalar, 2007: 197). İnsan kaynakları planlamasıyla, yeterli sayıda ve uygun kişilerin, doğru işte ve doğru zamanda bulundurulması sağlandığı gibi örgütün insan kaynağı ihtiyacı da belirlenir (Acar, 2009: 87). Ayrıca bu süreçte; örgütün tüm bölümleri için, bugün ve gelecekte nitelik ve nicelik olarak gerekli insan kaynağı ihtiyacı tahmin edilir ve bu ihtiyacın nereden, ne zaman ve nasıl karşılanacağını önceden belirlenir (Şimşek, 2005: 317).

İnsan kaynakları planlaması örgütün aşırı ya da eksik personelle çalışmasını önler, çevresel değişmelere örgütün uyum sağlayabilmesi için personelle ilgili faaliyetleri yönlendirir (Yüksel, 2007: 68). Planlama, mevcut personelin daha etkin ve verimli kullanılmasını sağlar. Değişim ancak yeterli, yetenekli ve yetişmiş insan kaynağ sayesinde başarılı bir biçimde yönetilebilir. Değişime başlamadan önce insan kaynakları ile ilgili gerekli çalışmaların yapılmasıyla örgütsel amaçları gerçekleştirmek daha kolay hale gelir. Bir örgütün insan kaynakları planlaması yapmasını gerekli kılan temel faktörler şöyle sıralanabilir (Yılmazer ve Eroğlu, 2008: 60):

- Teknolojide yaşanan sürekli gelişmeler,

- Yaşanan sosyal ve ekonomik krizler,

- Hızlı toplumsal ve kültürel gelişmeler, 
- İşgücü maliyetinin giderek artması,

- Yasal ve politik gelişmeler,

- Küreselleşmenin ortaya çıkardığı yenidünya düzeni ve yönetim anlayışı.

İnsan kaynağının seçiminde kullanılan süreç ve yöntemler, elde edilecek sonuçları doğrudan etkiler (Çolak, 2007: 86). Değişime ayak uydurmak isteyen örgütler, iyi yetişmiş elemanların seçimi yanında, insan kaynağını yaygın biçimde eğitme çabası içerisindedirler (Serinkan, 2007: 113). Bunlara ulaşmak için kullanılan teknikler de çalışanların ve örgütün ihtiyaçlarını yansıtmalıdır (Palmer ve Winters, 1993: 119). Eğitim örgütü değişime hazırlamada kullanılabilecek önemli faktörlerden ve araçlardan birisidir. Ancak eğitim ihtiyacının ve konularının belirlenmesi sürecinde örgütün değişim sürecinde ulaşmak istediği amaç ve hedefler göz önünde bulundurulmalıdır. Değişim sürecinde işe yarayacak niteliklerin yanı sıra değişimin felsefesi de çalışanlara kazandırılmalıdır. Değişim sürecinden kendilerinden ne istendiği ya da ne beklendiği eğitim sürecinde çalışanlara verilmelidir.

Değişime uyum sağlayabilmek için çalışanların eğitim sürecinden geçirilmesi gerekir. Eğitim, çalışanların gücünü, ustalıklarını ya da anlayışını artırmak, inanç ve değerlerini geliştirmek amacıyla yapılan, bilinçli bir değişim sürecidir (Simon vd, 1967: 341). Çalışanların, görevlerini daha etkin ve verimli bir biçimde yapabilmeleri için, insan kaynakları eğitiminden yararlanılır; bu süreçte bireylerin mesleki bilgileri geliştirilir; davranış, tutum, alışkanlık ve anlayışları değiştirilir. Çalışanlara kurumsal kültürün aşılanması, kişinin kendisine güveninin ve motivasyonunun artırılması, örgütte çalışanlar arasındaki ilişkilerin geliştirilmesi, ihtiyaç duyulan konularda bilgi, beceri ve davranış kazandırılması, eğitimin amaçları olarak benimsenebilir. Kısaca eğitimin amac1, bilgi toplumunun ve örgütsel değişimin ihtiyaç duyduğu insan tipinin yetiştirilmesi olmalıdır (Tınaz, 2000: 41-42).

Assl amacı çalışan bireyi çeşitli bilgi ve becerilerle donatarak örgütsel etkinliği artırmak olan eğitim faaliyetlerinin, örgütün ihtiyaçlarına en iyi cevap verecek şekilde planlanması ve programlanması gerekir. Örgütteki eğitim faaliyetleri örgütsel iyileşme ve gelişmeyi hedef almalıdır. Böylece değişim süreci desteklenmiş olur (Özçelik, 2009: 161). Örgüt geliştirmenin amac1, çalışanların becerilerini, bilgi ve tutumlarını sistematik bir şekilde olumlu yönde değiştirerek şimdiki ve gelecekteki işlerinde daha başarılı olmasını sağlamaktır. Örgütler, yoğun rekabet ortamında gerekli olan, örgütsel ve bireysel kapasite 
geliştirme ihtiyaçlarını, eğitim ve geliştirme faaliyetleriyle karşılayabilirler (Bingöl, 2008: 335).

Eğitim ve geliştirme, örgütsel verimliliğin ötesinde bireysel amaçların gerçekleştirilmesine de hizmet eder. Çalışanların değişen çevre şartlarına uyumunu kolaylaştırır. Eğitime yapılan yatırım, bireysel, örgütsel ve toplumsal gelişmeye katkıda bulunarak, makro planda ülke kalkınmasına destek sağlar. Eğitim, çalışanların motive edilmesinin bir aracı olup, onların eksik yönlerini görmesini ve meydana gelen yeniliklerden haberdar olmalarını sağlar (Kozak, 2009: 119).

Örgütsel etkinliği ve verimliliği artırmak için örgütte iş analizi yapılmalı, iş tanımları ve gerekleri hazırlanmalıdır. İş analizi, Örgütteki işlerin tek tek ele alınıp, özelliklerinin tespit edilmesi ve birbirleriyle ve bütünle olan ilişkilerinin belirlenmesi için yapılan çalışmadır (Bilgin, 2007: 31). Aynı zamanda bir işin en önemli yönlerini ortaya çıkararak, o işi tanımlama ve çözümleme sürecidir (Palmer ve Winters, 1993: 43). İş tanımı; iş analizleriyle toplanan verilerden yararlanılarak, her bir işin kapsamına giren eylemlerin, işlemlerin, sorumlulukların, görevlerin ve çalışma koşullarının yazılı olarak açıklanmasıdır (Bayraktaroğlu, 2008: 30). İş analiziyle işin içerdiği görevler, sorumluluklar ve işi üstlenecek kişilerde aranması gereken nitelikler sistematik biçimde incelenir (Can ve Kavuncubaş1, 2005: 53). İş gerekleri ya da iş nitelikleri ise, işin yerine getirilebilmesi için personelin taşıması gereken niteliklerdir. Bunlar; eğitim düzeyi, deneyim, zihinsel, fiziksel ve duygusal özellikleri ile davranışlarıdır (Bilgin, 2007: 40).

Örgütsel değişimi gerçekleştirmede çalışanların performans düzeyleri oldukça önemlidir. Değişimi benimsemiş ve motive edilmiş çalışanların performansı, değişim uygulamaları sırasında önemli bir destek oluşturur. Performans; bir çalışanın belirli bir zaman kesiti içinde kendisine verilen görevi yerine getirmek suretiyle elde ettiği sonuçlardır. Değişim lideri, çalışanların performansını artırmak için gerekli olan tedbirleri almalıdır (Bingöl, 2006: 321). Performans değerlendirmesi, personelle yöneticilerin birlikte amaçlar tespit etmesi, iletişimde bulunması, çabaların birleştirilmesi ve alınan sonuçların değerlendirilmesidir. Başka bir deyişle, performans değerlendirme; bir yöneticinin önceden belirlenmiş standartlarla karşılaştırma ve ölçme yoluyla çalışanların işteki performansının değerlendirilmesi sürecidir (Gürüz ve Özdemir, 2009: 210). Bu sürecin uygun bir şekilde tasarlanması ve uygulanması, ödüllendirme, terfi ya da tenzil, işten çıkarma ya da transfer 
uygulamaları gibi örgüt kararlarının verilmesinde kolaylık sağlar. Ayrıca, işgörenin geliştirilmesi sürecinde yöneticilere yardımcı olur. Diğer yandan işgörenin hem kariyer seçiminde hem de onun kendi zaman ve performansını yönetmesinde etkilidir (Gök, 2006: 40). Performans ölçme ve değerlendirme, sadece başarının ölçülmesi ile ilgili olmayıp, aynı zamanda insan potansiyelinin belirlenmesi, ölçülmesi ve geliştirilmesi sürecidir. Performans ölçülmesi sonucu tespit edilen potansiyelin geliştirilmesi ve eksikliklerin giderilmesi eğitim vasıtasıla mümkündür (Göksel, 2003: 54).

Performans değerlendirmenin amacı, kişiyi bütün yönleriyle ele almak, başarılarını ödüllendirmek ve eksikliklerinin giderilmesine imkân sağlamaktır (Örücü, 2003: 201). Değerlendirme hem örgüt hem de çalışan bakımından önemlidir. Başarılı işgören çalışmasının karşılığını görmeyi arzu ettiği gibi çalışmayan bir kişiye değer verildiğini görmesi onun morali bozar ve çalışma şevki kırar. Ayrıca yapılan değerlendirme sonucu kendi eksikliklerini görme imkânı elde eden işgören, bu eksiklikleri tamamlama ve yeteneklerini geliştirme fırsatı da bulmuş olur. Objektif ölçülere göre yapılan değerlendirme, işgörenin moral ve motivasyonunu yükseltir; aynı zamanda örgüte olan güven duygusunu artırır (Ertürk, 2009: 303).

Örgütsel değişim sürecinde örgütteki ücretleme sisteminden de yararlanmak mümkündür. Çalışanların moral ve motivasyonlarını yükseltmek, değişimle ilgili desteklerini sağlamak için ücretleme sistemi kullanılabilir. Ücret, çalışanın işverenden emeği karşılığında aldığı ekonomik değer (Şimşek ve Öge, 2009: 192) olup ücret ve ödül sistemleri, hem örgüt hem de çalışanlar için oldukça önemlidir. Ücret politika ve sistemlerinde, ücretin parasal boyutu yanında, örgütteki çalışanları motive edebilen değerli ve güçlü bir araç olma özelliği vardır. Ücret sistemleri, örgütü işgörenler için çekici kılan, çalışanların örgütteki sürekliliğini ve motivasyonunu sağlayan, örgütsel hedeflerin gerçekleştirilmesine yardımcı olan ve bu hedefleri destekleyen bir süreçtir (Gök, 2006: 46). Değişimi gerçekleştirmede ücretlendirme sistemi ya da politikaları oldukça etkilidir. Ücretlendirmenin temel amac1, en doğru ücret sistem ve uygulamalarıyla; çalışanların verimliliğini, motivasyonunu ve örgütsel performansı artırmak, böylece örgütsel değişimi gerçekleştirmektir (Benligiray, 2007: 179).

İnsan kaynağının değişim yönetimi sürecinde, değişimin amaçları doğrultusunda etkili ve verimli bir biçimde kullanılması, insan kaynakları yönetimi anlayışının başarıyla uygulanmasına bağlıdır. Onun ilke ve yöntemleri 
kadar, yöneticilerin bilgi, birikim ve becerileri de bu süreçte etkilidir. $\mathrm{Bu}$ da yönetim sanatını gündeme getirir. Bu sanatın en önemli yanlarından birisi de çalışanlardan yüksek performans elde edebilmektir. Bunun için örgütsel performansın başarılı bir biçimde yönetilmesi gerekir. Performans yönetiminin başarısı, hem bireysel hem de örgütsel performansın sürekli yükselmesini sağlar. Ayrıca bu performansların optimal bir seviyede sürdürülmesini de mümkün kılar. Zira değişim süreci örgüt için olağanüstü bir durum olup yüksek performansla çalışmayı gerekli kılar.

\section{F. Performans Yönetimi}

Değişim yönetiminin temel amac1 örgütsel etkinliği ve verimliliği artırmaktır. Bu amaca ulaşmada çalışanların performansı oldukça etkili olması sebebiyle örgütlerde performans yönetimi hayati öneme sahiptir. Bu bağlamda çalışanların performansı örgütsel değişimi gerçekleştirmek için kullanılmalı ve desteklenmelidir. Çalışanların performansları üzerinde pek çok faktör etkili olduğundan, performans yönetimi sürecinde bütün bu faktörlerin göz önüne alınması gerekir. Ayrıca örgütün içinde bulunduğu duruma göre de stratejik yöntemler uygulanmalıdır.

\section{Performans Yönetimi Kavramı}

Performans, bir amaca ulaşmak için gösterilen çabaların toplamıdır (Altıntaş, 2008: 3). Performans, genel olarak amaçlı ve planlanmış bir etkinlik sonucunda elde edileni, nicelik ve /veya nitelik olarak belirleyen bir kavramdir. Başka bir deyişle, belirlenmiş olan hedefe ulaşım seviyesinin ölçülmesidir. Bir işi yapan bireyin, bir grubun ya da bir kuruluşun o işle amaçlanan hedefe ne ölçüde ulaşılabildiğinin nicel ve nitel olarak ifadesidir. Kısacası bir işte gösterilen başarı derecesidir (Özer, 2009: 4-5). Performans çok çeşitli unsurların ya da boyutların bir araya gelmesiyle oluşmuştur. Performansın unsurları, sunulan mal ve hizmetin kaynă̆ına göre de değişebilir. Ancak literatürde performansın değişmeyen unsurları olarak ekonomiklik, verimlilik ve etkinlik kabul edilmektedir (Köseoğlu, 2005: 214).

Performans yönetim sistemi, başarının tanımlandığı ve paylaşıldığı, insanların başarı odaklı yönlendirildiği ve geliştirildiği, kısa ve uzun vadede yapılacakları kapsayan bir süreçtir. Bir başka deyişle, performans yönetimi, çalışanların mümkün olduğunca örgütün ihtiyaçlarına doğru, gereken etkinlik ve verimlilikte yönlendirilmesi ve desteklenmesidir (Öztürk, 2009: 36-37).

Performans yönetimi hedeflerle yönetim ilkesine dayanmaktadır. Hedeflerle yönetim, kısa, orta ve uzun vadeli hedeflerin belirlenmesi ve 
belirlenen bu hedefler doğrultusunda geliştirilen stratejilerin ve politikaların yönetimde kullanılmasıdır (Coşkun, 2007: 6). Performans yönetimi, yönetimin kontrol işlevinin en önemli faaliyetidir. Bir örgütün amaçlarına ulaşıp ulaşmadığının izlenmesi olan kontrol işlevi, performans hedeflerini belirlemeyi, performansı ölçmeyi, hedefler ile ulaşılan performansı karşılaştırarak aradaki farkları hesaplamayı ve bu farkların ortadan kaldırılması için harekete geçmeyi kapsamaktadır (Coşkun, 2007: 1). İnsan kaynağının örgüte katma değeri ile ilgili çalışmaların merkezinde, performans yönetimi konusu yer alır (Özer, 2008: 391). Performans ölçümü ve denetimi, kaynak savurganlığının önlenmesi ve yolsuzlukların önüne geçilebilmesi amacıyla örgütsel yönetimin önemli konuları arasında bulunmaktadır (Çukurçayır ve Eroğlu, 2004: 41).

\section{Performans Yönetimi Değişim Yönetimi İlişkisi}

Değişimin başarısı örgütsel performansa bağlıdır. Örgütsel performansın ölçülebilmesi ve değerlendirilebilmesi için de performans standartlarına ihtiyaç vardır. Performans sisteminin temeli olan performans standartlarına dayalı olarak yapılan analizler, performans değerlendirmesine ortam hazırlamaktadır. Performans standartlarının belirlenmesi hem çalışanlar hem de yönetim açısından önemlidir. İyi bir performans yönetimi için gerekli olan başlıca performans standartları; yazılı, kesin, ölçülebilir, ulaşılabilir, esnek, zamanı belli, meydan okuyucu ve yetkiyle uyumlu olmalı; aynı zamanda dikey ve yatay olarak bağdaşmalıdır (Özer, 2008: 401-402).

Performans yönetiminin amac1; bir taraftan örgütün vizyonu doğrultusunda hedeflerin belirlenmesi ve bu hedeflere çalışanların katkılarının sağlanması, diğer yandan da değişim sürecinde hedeflere ulaşırken çalışanların katılımlarının adil, sistemli ve ölçülebilir bir yöntemle değerlendirilmesidir. Ayrıca motive edici bir çalışma ortamının oluşturulması ve kişisel gelişimin desteklenmesi gerekir (Özer, 2009: 7-8). Performans yönetiminin genel amacı ise, çalışanların; örgütün etkinliğini, kendi becerilerini ve örgütsel değişime katkılarını sürekli iyileştirmektir. Ayrıca bireylerin ve grupların sorumluluk üstlendikleri bir kültür oluşturmaktır (Helvac1, 2002: 156). Performans yönetiminin amaçları şöyle sıralanabilir (Öztürk, 2009: 38):

- Örgüt performansını geliştirmek ve güçlendirmek,

- Takım performansinı artırmak,

- Performans odaklı bir kültür oluşturmak ve değişimde bu kültürden yararlanmak,

- Performans beklentilerinin tanımlanmasına yardımcı olmak, 
- Çalışanların motivasyon ve katılımını artırmak,

- İş tatmininin sağlanması, çalışanların potansiyellerini kullanması ve geliştirmesine yardımcı olmak,

- Tüm kurumda yapıcı ve açık iletişimi geliştirmek ve sürekli diyalog sürecini oluşturmak,

- Çalışanların işle ilgili beklenti ve umutlarını ifade etmelerine firsat tanımak,

- İş sorumluluklarını yazılı hale getirmek,

- Bireysel performans beklentileriyle örgütün hedeflerini buluşturmak,

- Yöneticilere koçluk ve kişisel gelişim için firsat yaratmak.

Performans yönetiminin başlangıç noktası, örgüte rekabet gücü kazandırmak için stratejilerin ve geleceğe dönük hedeflerin belirlenmesidir. İkinci aşaması ise, örgütün mevcut performans düzeyinin ölçülmesi ve değerlendirilmesidir. Bu aşamada, yönetim sistemleri ve süreçlerinin stratejilere uygunluğunun sağlanması gerekir. Bunu performansı geliştirmeye yönelik planlama süreci izler. Dördüncü aşama; performansı geliştirmek için alınacak önlemleri belirlemek ve uygulamaya koymaktır (Özer, 2008: 413). Performans yönetiminin en önemli ve son aşaması ise, performansın ölçümü sürecini oluşturan kontrol aşamasıdır. Kontrol, daha önce performans planlaması ile belirlenen ve uygulamaya konulan faaliyetlerin stratejik hedeflere ulaşılmasına ne kadar hizmet ettiğinin araştırılmasıdır. Ayrıca, genel olarak kişinin, grubun ya da örgütün herhangi bir konudaki etkinliğini birtakım özelliklere göre analiz etmeye ve başarı düzeyini belirlemeye yönelik çalışmalardır (Altıntaş, 2008: 6).

Performans yönetimini olumsuz yönde etkileyen pek çok faktör bulunmaktadır. Bunlar; yetersiz sistem tasarımı, yönetim ve paydaşların destek ve katılımlarının eksikliği, yetersiz motivasyon ve eksik bilgilendirme, çalışan ve yönetici arasında iletişim eksikliği, yöneticinin zamanı etkin kullanamaması, eşit ve adil olmayan uygulamalar şeklinde say1labilir (Öztürk, 2009: 67). Diğer yandan değişim sürecinin ortaya çıkardığ 1 çeşitli sorunlar performans yönetimini olumsuz yönde etkiler. Performans yönetimi, hem örgütteki bu değişime uyum sağlamak hem de bu sürece olumlu katkı sağlamak zorundadır. $\mathrm{Bu}$ nedenle değişim sürecindeki performans yönetimi olağan dönemden daha fazla güçlüklerle karşılaşır. Değişimi sürecinde kimi zaman yöneticilerden, kimi zaman da çalışanlardan kaynaklanan çeşitli sorunlar ortaya çıkabilir. Örgütte ortaya çıkan bu tür sorunlar, performans düşüklügünün belirtileri olarak 
değerlendirilebilir. Bu belirtiler şöyle sıralanabilir (Akgemci ve Güleş, 2009: 122-123):

- Verimin azalmasi,

- İş kalitesinin düşmesi,

- İşi tamamlamada yaşanan gecikmeler,

- Daha zor görev ve işlerden kaçınma,

- Sürekli şikâyetlerin dile getirilmesi,

- Çalışanlar arasında işbirliğinin azalması,

- Olumsuz geribildirimlerin artmasi,

- Hatalar ve başarısızlıklar için başkalarını suçlama eğiliminin artmas1,

- Çalışanların sürekli savunma durumuna geçmesi ve alınganlığın artmas1,

- Çalışanların görev yerlerini terk etmesi, arandığında bulunamamas1,

- İşe gelmeme ya da geç gelme davranışlarının ortaya çıkması.

Performans yönetimi sürecinde ağırlık, planlama ve kontrol fonksiyonları üzerindedir. Bu nedenle performans yönetim sürecinin aşamaları; performans planlaması, performansın ölçülmesi ve değerlendirilmesi olarak sayılabilir (Benligiray, 1999: 53). Performans yönetiminde, her örgüt kendi amaçlarına ve yönetim yapısına uygun olan performans ölçüm ve denetim sistemini belirler (Köseoğlu, 2004: 637). Yöneticinin performansı ölçebilmesi için, performansın göstergelerini belirleyebilecek ve tanımlayabilecek nitelikte olması gerekir. Performans ölçüm sistemi, işin hem etkinlik hem de verimliliğini ölçmek için kullanılan bir yöntemdir (Özer, 2009: 11). Ancak bu sistem kullanılırken, değişimin amaç ve hedefleriyle elde edilen sonuçlar mukayese edilmelidir. Amaç ve hedeflere hizmet etmeyen performans verileri, değişim sürecinin sabote edildiğinin birer göstergeleri olabilir. Örgütsel değişim sürecinin planlanandan daha uzun sürmesi, örgütsel kaynakların israf edilmesine yol açar.

Örgütsel etkinlik, verimlilik ve tutumluluğun sağlanıp sağlanmadığının belirlenebilmesi için, örgütün; amaç, program ya da faaliyetinin önceden belirlenmiş kriterlere göre ölçülmesi gerekir (Köseoğlu, 2004: 638). Ölçüm yapmak için, öncelikle zemini ölçülebilir duruma getirmek gerekir. "Şayet performansı ölçemiyorsan, yönetemezsin", sözü performans yönetiminin en 
önemli ilkesidir. Performansın ölçülmesi sırasında göz önünde bulundurulması gereken kriterler şöyle sıralanabilir (Öztürk, 2009: 151-152):

- Performans ölçülerinin, örgütün hedefleri ve rakamlarıyla mukayese edildiğinde bir anlamı olmalıdır.

- Seçilen performans ölçüleri, örgütle, bölümle ve bireyle ilgili olmalidir.

- Seçilecek performans ölçüleri, kuruma özel belirlenmelidir.

- Çıktıların ve sonuçların ölçümü yanında, başarılar ve davranışlar da ölçümde dikkate alınmalıdır.

- Performans ölçüleri, gözleme dayalı ve doğruluğu kanıtlanmış olmalidir.

- Performans ölçüleri konusunda uygulamaya yönelik bilgilendirme yapılmalı, diğer yöneticilerin önerileri alınmalidır.

- Kapsamlı olmalı ve performansla ilgili tüm etkileri içermelidir.

Performans değerlendirme, örgütlerde belirli amaçlara göre, personelin görevindeki başarı, tutum ve davranışları ile ahlakî durum ve özelliklerini belirleyen, örgütün başarısına olan katkılarını değerlendiren planlı ve çok evreli bir süreçtir (Bingöl, 2006: 322). Performans değerlendirmenin iki genel işlevi vardır. İlki, iş performansı hakkında bilgi edinmektir. Bu bilgi, yönetsel kararlar aşamasında gerekli olur. Ücret artışları, ikramiyeler, eğitim, disiplin, terfî ve başka yönetsel etkinliklere ilişkin kararlar genellikle performans değerlendirmesinden elde edilen bilgilere dayandırılır. İkinci işlevi, çalışanların iş tanımında ve iş analizinde tespit edilen standartlara ne ölçüde yaklaştı̆̆ına ilişkin geri bildirim sağlamaktır. Performans değerlendirmenin önemli işlevleri arasında; işgörenlerin eğitimi ve geliştirilmesi, eğitim program ve politikalarının değerlendirilmesi, işgörenleri seçme sürecinin geçerliliğinin belirlenmesi gibi önemli işlevleri de vardır (Helvacı, 2002: 159). Beklenen yararları sağlaması ve etkili sonuçlar vermesi açısından, değerlendirme sistemi; adil, geliştirici, motive edici, durumlara uygun, geçerli ve güvenilir, kapsamlı ve sürekli olmalı, aynı zamanda personelin katılımına imkân vermelidir (Can ve Kavuncubaşı, 2005: 170-172).

Performans değerlendirme, örgütsel değişimin yönetilmesi sürecinde pek çok alanda kullanılabilir. Elde edilen verilerden yola çıkılarak değişim sürecinin başarısı için gerekli olan önlemlerin alınması mümkün olur. Bir başka 
deyişle değişim sürecinde eksikliklerin giderilmesi ve performansın yükseltilmesi için gerekli çalışmaların yapılması imkânı ortaya çıkar. Performans değerlendirmesinin pek çok amacı bulunmaktadır. Gelişim, ödüllendirme, motivasyon ve yasal uygunluğun sağlanması performans değerlendirme amaçları arasında sayılabilir. Bu bağlamda örgütün performans değerlendirmeye yönelik genel amaçları şöyle sıralanabilir (Akgemci ve Güleş, 2009: 116-117):

- Çalışanların yetkinlikleri konusunda fikir sahibi olmak,

- Örgüt içinde gerçekleştirilmek istenen uygulamaların anlaşılma derecesini görebilmek,

- Örgüt kaynaklarının kullanılma etkinliğini analitik olarak ortaya çıkarabilmek,

- Gerçek olaylara ve verilere dayanan kararlar verebilmek,

- Örgüte sistem düşüncesi çerçevesinde bir bütün olarak bakabilmek,

- Örgütteki vizyon ve misyon paylaşımının seviyesini görebilmek,

- Hedeflere ulaşmada yardımcı olan süreçleri sorgulamak,

- Çalışanların yarattıkları katma değeri karşılaştırmalı olarak incelemek,

- Bireysel ve örgütsel eğitim ihtiyaçlarını tespit etmek,

- Örgütün gelişme eğilimini sürekli olarak yukarıda tutabilmek,

- Amaçlara ulaşmada etkili olan davranışları tespit etmek ve motive edebilmek,

- Aynı yapı içindeki bireysel ve örgütsel algılama farklılıklarını tespit etmek,

- Çalışanları ve çalışanların yeteneklerini tanımanın yanı sıra, çalışanların kendisini tanımasına yardımcı olmak.

Performans yönetimi, sadece performans düzeyinin belirlenmesi ile sınırlı kalmayacak kadar önemlidir. Bu nedenle örgütler, performans yönetimini dinamik bir süreç olarak değerlendirmektedir. Performans kriterleri olmadan performansı ölçmek, performans ölçülmeden de performansı yönetmek mümkün değildir. Örgütsel değişim süreci performans yönetiminin önemli katkılarıyla ancak gerçekleştirilebilir. Bu bağlamda performans yönetiminin örgütlere sağladığı yararlar şöyle sıralanabilir (Özer, 2008: 407):

- İş ve sonuçlar üzerinde yönetim kontrolünü artırır. 
Tunçer, P. / Sosyal Bilimler Araştırmaları Dergisi. I, (2012): 131-156

- Olumsuz sorunları erken teşhis etmek için yönetim etkinliğini artırır.

- Objektif verileri birleştirir ve objektif bir örgüt oluşur.

- Çalışanları nesnel standartlara uygun çalışmaya motive eder.

- Yönetimin beklentilerine katılımı ve katkıda bulunmayı sağlar.

- Standartlarla ilgili iyileştirmeyi ya da disiplin cezalarını desteklemeyi, nesnel bir biçimde ortaya koyar.

- Çalışanlara ve yönetime daha objektif bir yönetim sistemi sağlar.

- Yönetimin malî konularda ve terfi için kararlar alabilmesine imkân verir.

- Her çalışan için merkezî performans kayıt sistemi sağlar.

\section{SONUÇ}

Günümüzdeki bilimsel ve teknolojik gelişmeler neticesinde pek çok şey değişmekte ve örgütlerde bu değişime ister istemez uyum sağlamak zorunluluğu duymaktadır. Çünkü rekabet yoğun ve çetindir; aynı zamanda da acımasızdır. Üretim hız ve kalitesiyle birlikte müşteri talepleri artmıştır. Örgütsel verimliliği artırmak için bulunan yeni yöntem ve teknikler, teknolojik gelişmelerle desteklenmektedir. Bu bağlamda örgütler rekabet avantaj1 yaratabilmek ve başarılı olabilmek için bu değişimi ve dönüşümü gerçekleştirmek zorundadırlar. Ancak bu değişimin kurumsal anlamda başarılı olabilmesi ve değişim sürecinin iyi yönetilebilmesi için insan kaynağından etkili bir biçimde yararlanmalıdır.

İnsan kaynağının kalitesi örgütsel değişimde bir avantaj yaratabilir. Çünkü yeterli, yetenekli ve eğitimi çalışanların değişime ayak uydurmaları daha kolay olacaktır. Bu nedenle örgütün insan kaynağı planlamasının, iş analizi, iş tanımları ve gereklerinin son derece iyi yapılması ve bu verilere göre eleman alınması gerekir. Eğer eldeki personel örgütün vizyon, misyon ve stratejik planlarına uygun değilse değişimi gerçekleştirmek ve yönetmek oldukça zor olacaktır. Bu durumda mevcut personelin eğitilmesi, geliştirilmesi ve ihtiyaçlara uygun hale getirilmesi gerekir.

Değişimi gerçekleştirecek ve uygulayacak olan çalışanların memnun edilmesi, onlara değer verilmesi, motivasyonu ve performanslarının artırılması için gerekli ve yeterli tedbirlerin alınması bu süreçte oldukça etkili olacaktır. Adil, eşit, dürüst ve samimi davranılmadığında performansları düşen çalışanlar, örgüte yabancılaşmaya başlar; sonuçta ilk firsatta örgütü terk ederler. İnsan kaynağının kıymetini bilmeyen, onu elinde tutamayan ve ondaki potansiyelden 
ve performanstan yeterince faydalanamayan örgütlerin değişimi başarılı bir şekilde gerçekleştirmesi beklenemez.

Değişimin başarısı insan kaynağının etkin ve verimli kullanılmasına; çalışanların tatmin edilmesine ve beklentilerinin karşılanmasına bağlıdır. İnsan kaynağına gerekli özeni göstermeyen ve onun için gerekli harcamayı yapmayan örgütler, ondan mevcut olan potansiyeli kullanamadığı gibi insan kaynakları yönetiminde ortaya çıkacak başarısızlık nedeniyle oluşacak stres, çatışma ve kriz, değişimin gerçekleştirilmesini engel olacaktır.

Örgütsel değişimi gerçekleştirmede kullanılabilecek yönetim tekniklerinden bir diğeri de performans yönetimidir. Değişim sürecinde planlanan amaç ve hedeflere ulaşıp ulaşmadığının izlenmesi ve kontrol edilmesi performans yönetimi ile sağlanabilir. Sonuç odaklı bir yaklaşım olan performans yönetimi, performans standartları oluşturarak örgütsel performansı ölçmeye ve artırmaya çalışır. Böylece değişim süreci sonunda ulaşılmak istenen hedeflerin sürekli bir biçimde kontrolüne yardımcı olur. Değişim yönetimi, amaç ve hedeflerini gerçekleştirmek için performans yönetiminden yararlanır. Örgütsel değişimin başarısı, belirlenen amaçlar doğrultusunda örgütsel performansın kullanılmasına bağlıdır.

Performans yönetimi sayesinde örgütsel savurganlık önlendiği gibi verimlilik de artar. Örgütsel değişim sürecinde performans yönetimi tekniğinden yararlanılması durumunda değişimin gerçekleştirilmesi bir ivme kazanır. Değişim ve performans yönetimlerinin her ikisinin hedefi de örgütsel etkinliği ve verimliliği artırmaktır. Değişim yönetimi amaçlarını gerçekleştirirken pek çok yol ya da yöntemden yararlanmakla birlikte, insan kaynakları ve performans yönetimi teknikleri vasıtasıyla örgütsel etkinliği ve verimliliği daha kısa sürede ve kalıcı olarak sağlayabilir.

\section{KAYNAKÇA}

Acar, A. C. (2009), “İnsan Kaynakları Planlaması ve İşgören Seçimi”, İnsan Kaynakları Yönetimi, 4. Bask1, Beta Yayınları, İstanbul.

Akgemci, T., Güleş, H. K. (2009), İşletmelerde Stratejik Yönetim, Gazi Kitabevi Yayınları, Ankara.

Altıntaş, A. (2008), "Mahalli İdarelerde Performans Yönetimi ve Riskleri”, Sayıştay Dergisi, Sayı 69, Nisan-Haziran.

Barutçugil, İ. (2004), Stratejik İnsan Kaynakları Yönetimi, Kariyer Yayınları, İstanbul. 
Bayraktaroğlu, S. (2008), İnsan Kaynakları Yönetimi, 3. Bask1, Sakarya Yayınları, Sakarya.

Beeson, Ian and Chris Davis, (2000, "Emergence and Accomplishment in Organizational Change", Journal Organizational Change Management, Vol. 13, No. 2.

Benligiray, S. (1999), İnsan Kaynakları Açısından Otellerde Performans Yönetimi, Anadolu Üniversitesi Yayınları, Yayın No. 1174, Eskişehir.

Benligiray, S. (2007), "İnsan Kaynakları Yönetimi ve Örgütlenmesi”, İnsan Kaynakları Yönetimi, (Ed. Ramazan Geylan), Anadolu Üniversitesi Yayınları, Eskişehir.

Bilgin, L. (2007), “İş Analizi”, İnsan Kaynakları Yönetimi, (Ed. Ramazan Geylan), Anadolu Üniversitesi Yayınları, Eskişehir.

Bingöl, D. (2006), İnsan Kaynakları Yönetimi, 6. Baskı, Arıkan Yayınları, İstanbul.

Bingöl, D. (2008), “İnsan Kaynakları Yönetimi”, Genel İşletmecilik, (Ed. Mithat Ünver), Detay Yayınları, Ankara.

Burnes, B. (1997), "Organizational Choice and Organizational Change", Management Decision, Vol. 35, No. 10.

Buzan, Tony, Tony Dottino, Richard Israel (2001), Akıllı Lider, (çev. Serdar Uçar), İstanbul:Alfa Yayınları, İstanbul.

Can, H.; Kavuncubaşı, Ş. (2005), Kamu ve Özel Kesimde İnsan Kaynakları Yönetimi, 5. Bask1, Siyasal Kitabevi Yayınları, Ankara.

Cornell, J. (1996), "Aspects of the Management of Change", Journal of Management in Medicine, Vol.10, No. 2.

Coşkun, A. (2007), Stratejik Performans Yönetimi ve Performans Karnesi, 2. Bask1, Literatür Yayınları, İstanbul.

Çetin, C. (2008), Yöneticilerin Liderlik Stilleri: Değişim Yönetimi ve Ekip Çalışması Arasındaki İlişkilerin Çok Yönlü Olarak Değerlendirilmesi, İstanbul Ticaret Odası Yayınları, İstanbul.

Çolak, A. (2007), "İnsan Kaynağını Bulma ve Seçme”, İnsan Kaynakları Yönetimi, (Ed. Uğur Dolgun), Ekin Yayınları, Bursa.

Çukurçayır, M. A.; Eroğlu, H. T. (2004), "Yerel Yönetimlerde Yeniden Yapılanmaya Farklı Bir Yaklaşım: Verimlilik ve Başarı Karnesi (Balanced Scorecard)", Sayıştay Dergisi, Sayı 53, Nisan-Haziran.

Davis, K. (1988), İşletmede İnsan Davranışı: Örgütsel Davranış, (çev. Kemal Tosun, Tomris Somay, Fulya Aykar, Can Baysal, Ömer Sadullah, 
Semra Yalçın), 3. Bask1, İstanbul Üniversitesi İşletme Fakültesi İşletme İktisadı Enstitüsü Yayınları, Yayın No:98, İstanbul.

Dolgun, U. (2007), “İnsan Kaynakları Yönetimine Giriş”, İnsan Kaynakları Yönetimi, (Ed. Uğur Dolgun), Ekin Kitabevi Yayınları, Bursa.

Drucker, P. F. (2000), 21. Yüzyıl İçin Yönetim Tartışmaları, (çev. İrfan Bahçıvangil, Gülenay Gorbon), 2. Bask1, Epsilon Yayınları, İstanbul.

Duck, J. D. (1999), “Değişim Yönetimi”, Değişim, (çev. Meral Tüzel), MESS Yayınları, İstanbul.

Düren, A. Z. (2000), 2000'li Yıllarda Yönetim, Alfa Yayınları, İstanbul.

Ertürk, M. (2009), İşletme Biliminin Temel İlkeleri, 7. Baskı, Beta Yayınları, İstanbul.

Genç, N. (2005), Yönetim ve Organizasyon: Çağdaş Sistemler ve Yaklaşımlar, 2. Bask1, Seçkin Yayınları, Ankara.

Gök, S. (2006), İnsan Kaynakları Yönetimi: 21. Yüzyılda, Beta Yayınları, İstanbul.

Göksel, A. (2003), “İnsan Kaynaklarında Eğitim ve Performans Ölçümü”, İşletmecilikte Çağdaş Yönelimler, (Ed. Birol Bumin), Gazi Kitabevi Yayınları, Ankara.

Gürüz, D., Yaylacı Özdemir, G. (2009), İnsan Kaynakları Yönetimi, 4. Bask1, MediaCat Yayınları, İstanbul.

Helvac1, M. A. (2002), "Performans Yönetimi Sürecinde Performans Değerlendirmenin Önemi”, Ankara Üniversitesi Eğitim Bilimleri Fakültesi Dergisi, Cilt 35, Sayı 1-2.

Hitt, Michael A., J. Stewart Black, Lyman W. Porter (2009), Management, Second Edition, Pearson Prentice Hall, New Jersey.

Hodgetts, R. M. (1997), Yönetim: Teori, Süreç ve Uygulama, (çev. Canan Çetin, Esin Can Mutlu), Der Yayınları, İstanbul.

Karalar, R. (2007), Genel İşletme, 3. Baskı, (yky), Eskişehir.

Kozak, M. A. (2009, İnsan Kaynakları Yönetimi, 3. Bask1, Detay Yayınları, Ankara.

Köseoğlu, Ö. (2004), "Performans Ölçümü Yönetimi ve Belediye Yönetimlerine Uygulanabilirliği”, Yerel Yönetimler Kongresi, Dünden Bugüne Yerel Yönetimlerde Yeniden Yapılanma Bildiriler Kitabı, (3-4 Aralık), Onsekiz Mart Üniversitesi Biga İ.İ.B.F. Yayınları, Çanakkale.

Köseoğlu, Ö. (2005), "Belediyelerde Performans Yönetimi”, Türk İdare Dergisi, Say1 447, Haziran. 
Linver, Sandy (ty), Konuşma Eğitimi, (çev. Aliye Özlü), Mert Yayıncılık, İstanbul.

Maxwell, John C. (1998), İçinizdeki Lideri Geliştirmek, (çev. Selim Yeniçeri), Beyaz Yayınları, İstanbul.

Örücü, E. (2003), Modern İşletmecilik, 3. Bask1, Gazi Kitabevi Yayınları, Ankara.

Özçelik, O. (2009), "Eğitim ve Geliştirme", İnsan Kaynakları Yönetimi, 4. Baskı, Beta Yayınları, İstanbul.

Özer, M. A. (2008), 21. Yüzyılda Yönetim ve Yöneticiler, Nobel Yayınları, Ankara.

Özer, M. Akif (2009), "Performans Yönetimi Uygulamalarında Performansın Ölçümü ve Değerlendirilmesi”, Sayıştay Dergisi, Sayı 73, NisanHaziran.

Öztürk, Ü. (2009), Performans Yönetimi, Alfa Yayınları, İstanbul.

Pritchar, B. (2010), "Change Management from An Engineers Perspective" Change Management, http://irc.queensu.ca/articles/ engineersperspective, (Erişim tarihi: 8 Ağustos 2010).

Palmer, Margaret, Kenneth T. Winters, (1993), İnsan Kaynakları, (çev. Doğan Şahiner), Rota Yayınları, İstanbul.

Robbins, Stephan P., David A. DeCenzo (2008), Fundamentals of Management, Sixth Edition, Pearson Prentice Hall, New Jersey.

Sabuncuoğlu, Z. (2000), İnsan Kaynakları Yönetimi, Ezgi Kitabevi Yayınları, Bursa.

Sabuncuoğlu, Z.; Tüz, M. (1998), Örgütsel Psikoloji, 3. Baskı, Alfa Yayınları, Bursa.

Schumacher, Wolf D. (2010), "Change Management Intervention Models Cont." Managing Barriers to Business Reengineering Success: Capter 4b, http://www.prosci.com/w4b.htm (Erişim tarihi:11 Ağustos 2010).

Serinkan, C. (2007), "İnsan Kaynağının Eğitimi ve Eğitim Yönetimi”, İnsan Kaynakları Yönetimi, (Ed. Uğur Dolgun), Ekin Yayınları, Bursa.

Simon, H. A., D. W. Smithzurg, V. A. Tompson (1967), Kamu Yönetimi, (çev. Cemal Mihcıoğlu), İkinci Kitap, TODAİE Yayınları, Ankara.

Şimşek, M. Ş. (2005), İşletme Bilimine Giriş, 12. Baskı, (yky), Konya.

Şimşek, M. Ş.; Öge, H. S. (2009), İnsan Kaynakları Yönetimi, 2. Baskı, Gazi Kitabevi Yayınları, Ankara.

Tınaz, P. (2000), Organizasyonlarda Etkili Öğrenme, MESS Yayınları, İstanbul. 
Toffler, A. (1989), Uyumlu Şirket, (çev. Yakut Güneri), İlgi Yayınları, İstanbul. Yazıc1, S. (2001), Öğrenen Organizasyonlar, Alfa Yayınları, İstanbul.

Yeniçeri, Ö. (2002), Örgütsel Değişmenin Yönetimi, Nobel Yayınları, Ankara.

Yılmazer, A.; Eroğlu, C. (2008), İnsan Kaynakları Yönetimi, Seçkin Yayınları, Ankara.

Yüksel, Ö. (2007), İnsan Kaynakları Yönetimi, 6. Bask1, Gazi Kitabevi Yayınları, Ankara.

Werkman, Renate A. (2009), "Understanding Failure to Change: A Pluralistic Approach and Five Patterns", Leadership \& Organization Development Journal, Vol. 30, No. 7.

White, Rupert E. (1998), Takım Lideri, (çev. Ali Çimen), Timaş Yayınları, İstanbul.

White, L. (2000), "Changing the whole system in the public sector"; Journal of Organizational Change Management, Vol. 13, No. 2. 